\title{
Gender Variation in Pattern of Mandibular Third Molar Impaction
}

\author{
Obuekwe $\mathrm{ON}^{1}$ and Enabulele $\mathrm{JE}^{2 *}$ \\ ${ }^{1}$ Department of Oral and Maxillofacial Surgery, University of Benin, Benin City, Edo State, Nigeria \\ ${ }^{2}$ Department of Restorative Dentistry, University of Benin, Benin City, Edo State, Nigeria
}

Received: December, 16, 2016; Accepted: February, 20, 2017; Published: February, 27, 2017

*Corresponding author: Enabulele Joan, Department of Restorative Dentistry, University of Benin Teaching Hospital. Edo State, Nigeria, Tell:+2348037275813;E-mail:emien.enabulele@uniben.edu

\begin{abstract}
A tooth is said to be impacted when it is obstructed on its path of eruption with the most commonly impacted tooth being the third molar. Various factors have been reported to cause obstruction in the path of eruption of the third molar and these include adjacent tooth, bone as well as soft tissue. Lack of space in the dental arch for the third molar to emerge as well as pathological lesions, stunted growth of tooth germ following nutritional deficiency, irradiation and physical trauma have been implicated in the etiology of third molar impaction [1].
\end{abstract}

There are varying reports regarding the prevalence of impacted third molars. Impacted third molars are more likely to occur in the mandible than in the maxilla [2,3]. However, studies have consistently shown that mesioangular impaction is the most common angulations of impaction of mandibular third molars [1,2,4-6].

A few studies $[4,6-8]$ tried to determine if there are any gender variations in mandibular third molar impaction with varying reports about the association of gender with third molar impaction. Previous studies $[2,4]$ reported no statistically significant difference between gender and mandibular third molar impaction while another study [9] reported significant association between gender and number of impacted teeth as well as the presence of impacted mandibular teeth.

With the varying reports regarding the association of gender to third molar impaction, this study was designed to determine the gender variation in mandibular third molar impaction among a group of Nigerian dental patients.

\section{Methodology}

This was a prospective cross sectional study involving patients presenting with impacted mandibular third molars to the Dental Centre of the University of Benin Teaching Hospital.

The data collection instrument was a pre-tested interviewer administered questionnaire. The questionnaire elicited information on demographic characteristics, number and type of impacted mandibular third molar, caries and cervical resorption status of the adjacent second molar and symptoms associated with the impacted mandibular third molar.

The standard International Lab our occupational classifica- tion system was adapted to classify occupation into five (5) socioeconomic groups: Professionals and managerial officers and retirees of this type (e.g. doctors, lawyers), skilled workers (e.g. teachers, nurses), semi-skilled workers (e.g. artisans), unskilled workers (e.g. traders) and dependants (students and other unemployed individuals).

Inclusion criteria were all consenting patients with at least one impacted mandibular third indicated for extraction. Informed consent was obtained from all the participants. Ethical approval was obtained from the Ethics and Research Committee of the College of Medical Sciences, University of Benin before commencement of the study.

Periapical radiographs of the impacted mandibular third molars were exposed using the long cone paralleling technique and a digital probe to enable classification of the type of impaction and any other radiographic findings. The long cone paralleling technique was used for this study due to the fact that it is regarded as the technique of choice following its reduced radiation dose; less magnification and demonstration of the true relationship between the bone height and adjacent teeth [10].

The impacted mandibular third molars were classified using the winter's classification based on the inclination of the long axis of the impacted third molar to the long axis of the second molar. The tooth was classified as mesio-angular when the impacted third molar is tilted towards the second molar in a mesial direction; disto-angular when the long axis of the impacted third molar is angled distally / posteriorly away from the second molar; horizontal when the long axis of the impacted third molar is horizontal and vertical when the long axis of the impacted third molar is parallel to the long axis of the second molar [11].

The impacted mandibular third molars were also classified as partial impaction when the superficial portion of the tooth was covered only by soft tissue but the height of the tooth's contour was below the level of the surrounding alveolar bone and complete impaction when the tooth was completely encased in bone so that when the gingival is cut and reflected back, the tooth is not seen [12]. 
The data so obtained was analyzed using IBM Statistical Package for Social Sciences (SPSS) version 21.0. The analysis was done using frequency distribution, cross tabulations, test of significance with chi square. $P<0.05$ was considered statistically significant.

\section{Results}

A total of 151 patients with 181 impacted mandibular third molars were recruited for this study which spanned over two years (June 2014- July 2016).

There was a female preponderance with male female ratio of 1:1.8. The age of the participants ranged from 17 to 81 years with a mean age of $32.52 \pm 10.73$ years. More than half of the participants $(51.7 \%)$ were in the third decade of life. Dependants accounted for $35.1 \%$ of the participants while $27.2 \%$ were skilled workers (Table 1).

Majority (78.3\%) presented with one impacted mandibular third molar. The left mandibular third molar accounted for $59.7 \%$ of the impacted mandibular third molar (Figure 1).

Partial impaction was observed in $73.5 \%$ of the participants (Figure 2). Mesioangular impaction was the most frequently encountered impaction (55.8\%) with vertical impaction accounting for $21.0 \%$ (Table 2).

More than half $(53.6 \%)$ of the impacted mandibular third molar had contact with the adjacent second molar. Cervical caries was noticed on $45.9 \%$ of the adjacent second molars while $7.7 \%$ of the adjacent second molars had radiographic findings suggestive of root resorption. Pain was reported by $70.2 \%$ of the participants.

There was no statistically significant association between

Table 1: Socio-demographic characteristics of the participants

\begin{tabular}{|c|c|c|c|}
\hline & Characteristics & Frequency & Percent \\
\hline Gender & Male & 54 & 29.8 \\
\hline Age (years) & Female & 97 & 53.6 \\
\hline & $21-30$ & 5 & 2.8 \\
\hline & $31-40$ & 78 & 51.7 \\
\hline Occupation & $>40$ & 26 & 27.8 \\
\hline & Professional & 19 & 17.2 \\
\hline & Skilled worker & 41 & 12.6 \\
\hline & Unskilled worker & 32 & 27.2 \\
\hline Marital & Dependant & 53 & 21.2 \\
\hline status & Single & 78 & 35.1 \\
\hline & Married & 73 & 43.1 \\
\hline & Total & $\mathbf{1 5 1}$ & $\mathbf{1 0 0 . 0}$ \\
\hline & & & \\
\hline & & & 40.3 \\
\hline
\end{tabular}

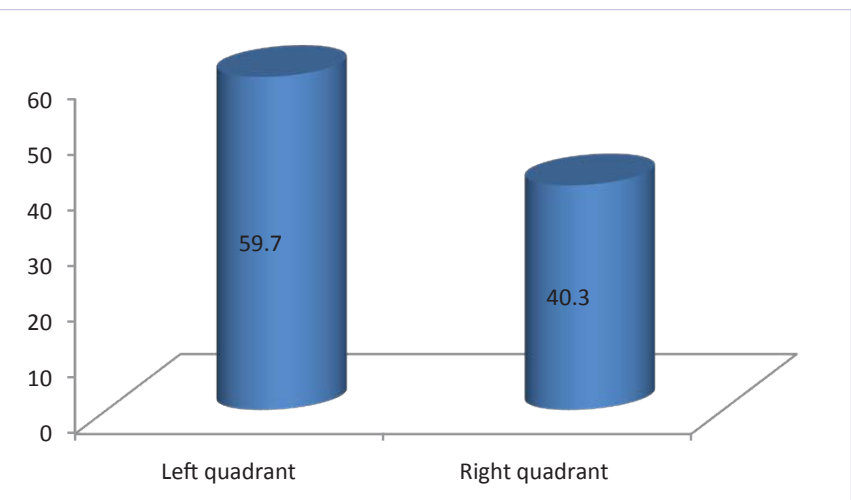

Figure 1: Distribution of impacted mandibular third molar by quadrant

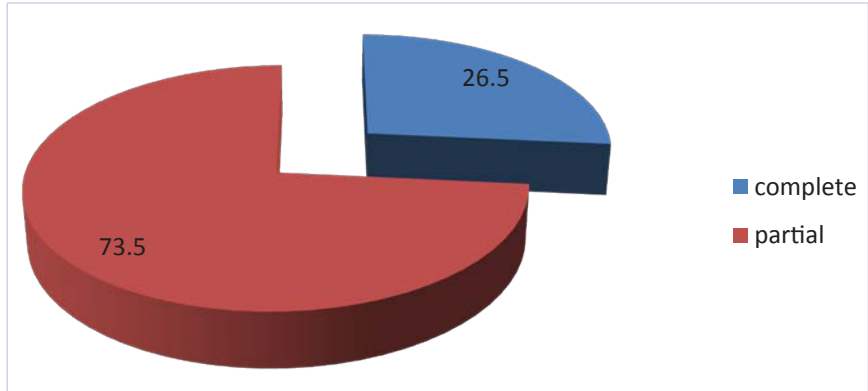

Figure 2: Distribution of impaction of the mandibular third molars

\begin{tabular}{|c|c|c|}
\hline \multicolumn{2}{|c|}{ Table 2: Distribution of impaction by winter's classification } \\
\hline Type of impaction & Frequency & Percent \\
\hline Mesioangular & 101 & 55.8 \\
\hline Distoangular & 24 & 13.3 \\
\hline Horizontal & 18 & 9.9 \\
\hline Vertical & 38 & 21.0 \\
\hline Total & 181 & 100.0 \\
\hline
\end{tabular}

gender and number of impacted mandibular third molar as well as whether the mandibular third molar was located on the right or left quadrant. Furthermore, there was no statistically significant association between gender and whether the impacted mandibular third molar was completely or partially impacted.

However, there was statistically significant association between gender and type of impaction (Winter's classification) ( $p$ $=0.025)$. A higher percentage (68.0\%) of females presented with Mesioangular impaction compared to males (44.4\%). A higher percentage of males presented with distoangular, horizontal and vertical impaction (Table 3).There was no statistically significant association between gender and presence of distal caries or root resorption on the adjacent second molar.

More females compared to males presented at less than 20 years of age while more males presented in the third decade of life however this was not statistically significant $(p=0.69)$ (Table 4). 
Table 3: Association between gender and winter's classification of the impacted mandibular third molar.

\begin{tabular}{|c|c|c|c|c|c|}
\hline \multirow[b]{2}{*}{ Gender } & \multicolumn{4}{|c|}{ Winter's classification } & \multirow{2}{*}{$\begin{array}{l}\text { Total } \\
\text { n (\%) }\end{array}$} \\
\hline & $\begin{array}{c}\text { Mesioangular } \\
\mathrm{n}(\%)\end{array}$ & $\begin{array}{c}\text { Distoangular } \\
\mathrm{n}(\%)\end{array}$ & $\begin{array}{c}\text { Horizontal } \\
\mathrm{n}(\%)\end{array}$ & $\begin{array}{c}\text { Vertical } \\
\mathrm{n}(\%)\end{array}$ & \\
\hline Male & $24(44.4)$ & $6(11.1)$ & 9 (16.7) & $15(27.8)$ & $54(100.0)$ \\
\hline Female & $66(68.0)$ & $9(9.3)$ & $6(6.2)$ & $16(16.5)$ & $97(100.0)$ \\
\hline Total & $90(59.6)$ & 15 (9.9) & $15(9.9)$ & $31(20.5)$ & $\begin{array}{l}151 \\
(100.0)\end{array}$ \\
\hline \multicolumn{6}{|l|}{$P=0.025$} \\
\hline
\end{tabular}

Table 4: Association between gender and age of the participants

\begin{tabular}{|l|l|l|l|l|l|}
\hline \multirow{3}{*}{ Gender } & \multicolumn{3}{|l}{ Age (years) } & \multicolumn{2}{l|}{$\begin{array}{l}\text { Total } \\
\text { n (\%) }\end{array}$} \\
\cline { 2 - 7 } & $\begin{array}{l}<\mathbf{2 0} \\
\mathbf{n}(\%)\end{array}$ & $\begin{array}{l}\mathbf{2 1 - 3 0} \\
\mathbf{n}(\%)\end{array}$ & $\begin{array}{l}\mathbf{3 1 - 4 0} \\
\mathbf{n}(\%)\end{array}$ & $\begin{array}{l}>\mathbf{4 0} \\
\mathbf{n}(\%)\end{array}$ & \\
\hline Male & $1(1.9)$ & $31(57.4)$ & $14(25.9)$ & $8(14.8)$ & $54(100.0)$ \\
\hline Female & $4(4.1)$ & $47(48.5)$ & $28(28.9)$ & $\begin{array}{l}18 \\
(18.6)\end{array}$ & $97(100.0)$ \\
\hline Total & $5(3.3)$ & $78(51.7)$ & $42(27.8)$ & $\begin{array}{l}26 \\
(17.2)\end{array}$ & $\begin{array}{l}151 \\
100.0)\end{array}$ \\
\hline$P=0.69$ & & & & & \\
\hline
\end{tabular}

\section{Discussion}

Gender specific trajectories have been observed in the relationship between the growing jaws and tooth eruption complex [13]. Giving this fact, it is important that gender variations associated with impacted teeth be understood.

Female preponderance of impacted third molars have been reported by previous studies [4, 6-9,14-17] and this was also observed in this study. However, there are other studies that reported no gender difference $[4,5,18]$ and male preponderance [19]. This supports the assertion that there are sex-specific mandibular traits with the sexual dimorphism clearly observed with bigger jaw bone in males [20]. The possibility of dietary influence on the physique, role of genetic factors or a combination of genetic and dietary factors have been proposed to have effect on low prevalence of impacted third molars [5] this may be the reason for the fewer number of males who presented compared to females.

Adequate development of the mandible with provision of enough space to accommodate the third molar which is usually the last tooth to erupt may reduce the prevalence of mandibular third molar impaction [21].Impacted mandibular third molar is believed to be as a result of stoppage of jaw growth in women at the time third molars erupt where as in males the growth of the jaw continues beyond the eruption time of the third molars [16]. This may explain why more females compared to males presented at earlier ages.Mesioangular impaction was reported as the most common impaction in males[4,17] while the most common impaction reported in females was distoangular impaction $[2,4]$. This is contrary to the findings of this study where a higher percentage of females presented with mesioangular impaction compared to males. Failure of mandibular third molar to erupt has been shown to be most affected by lack of space in the alveolar arch between the distal of the second molar and the ascending ramus [22]. This may account for why more females presented with mesioangular impaction as mandibular growth stops in females [16] leading to shortage of retromolar space which is a major aetiological factor of mandibular third molar impaction [23].

The findings of this study showed that there was no statistically significant association between gender and number of impacted mandibular third molar as well as whether the mandibular third molar was located on the right or left quadrant, similar to reports of a previous study [4] and differs from other studies [9,17] that observed association between gender and number of impacted mandibular third molar

Studies $[24,25]$ have reported distal caries on the adjacent second molar associated with impacted third molar. This study recorded a higher prevalence of distal caries compared to previous studies [24,25] though there was no association with gender as reported by a previous study [24].

Risk factors (patient's age and impaction depth) for external root resorption have been evaluated ${ }^{26}$ but gender was not evaluated. The finding of this study showed gender had no influence on occurrence of external root resorption on the adjacent second molar.

\section{Conclusion}

There is gender variation in prevalence, age at presentation as well as type of impaction of mandibular third molar but no gender influence in occurrence of distal caries and external root resorption of the adjacent second molar.

\section{References}

1. Rahman SA, Alam MK, Woei KC, Shaari R. Pattern of angulations of mandibular third molar impaction in a Malaysian population: a retrospective radiographic investigation. Inter Med J. 2014;21(1):120122.

2. Hatem M, Bugaighis I, Taher EM. Pattern of third molar impaction in Libyan population: a retrospective radiographic study. Saudi J Dent Res. 2016;7(1):7-12. doi:10.1016/j.sjdr.2015.04.005

3. Pillai AK, Thomas S, Paul G, Singh SK, Moghe S. Incidence of impavted third molars: a radiographic study in People's hospital, Bhopal, India. J Oral biolcraniofac Res. 2014;4(2):76-81. doi: 10.1016/j. jobcr.2014.04.001

4. Al-Anqudi SM, Al-Sudairy S, Al-Hosni A, Al-Maniri A. Prevalence and pattern of third molar impaction. A retrospective study of radiographs in Oman. Sultan qaboosuniv Med J. 2014;14(3):e388-392.

5. Osunde OD, Bassey GO. Pattern of impacted mandibular third molars in Calabar, Nigeria. Afr J Med Health Sci. 2016;15(1):14-17. doi: 10.4103/2384-5589.183886

6. Hashemipour MA, Tahmasbi-Arashlow M, Fahimi-Hanzaei F. Incidence of impacted mandibular and maxillary third molars: a radiographic study in a south east Iran population. Med Oral Patol Cir Bucal. 2013;18(1):e140-145. doi: 10.4317/medoral.18028 
7. Akinwande JA. Mandibular third molar impaction- a comparison of two methods of predicting surgical difficulty. Niger Dent J. 1991;10:37.

8. Santamaria J, Arteagoitia I. Radiologic variables of important clinical significant in the extraction of impacted mandibular molars. Oral Surg Oral Med Oral Pathol Oral radiolendod. 1997;84:469-473.

9. Eshqhpour M, Nezadi A, Moradi A, Shamsabadi RM, Rezaei NM, Nejat A. Pattern of mandibular third molar impaction: a cross-sectional study in northeast of Iran. Niger J clinpract. 2014;17(6):673-677. doi: 10.4103/1119-3077.144376

10. Oenning ACC, Melo SLS, Groppo FC, Haiter-Nelo F. Mesial inclination of impacted molars and its propensity to stimulate external root resorption in second molars; a cone beam computed tomographic evaluation. J Oral maxillofacsurg. 2015; 73:379-386. doi: 10.1016/j. joms.2014.10.008

11. Winter GB. Impacted mandibular third molar. St Louis, American Medical Book Co. 1926:241-279.

12. Santhosh Kumar MP, Aysha S. Angulations of impacted mandibular third molar: A radiographic study in Saveetha Dental College. J Pharm Sci Res. 2015;7(11):981-983.

13. Glowacki J, Christoph K. Gender differences i the growing, abnormal and aging jaw. Dent Clinics North Am. 2013;57(2):263-280. doi. org/10.1016/j.cden.2013.01.005

14. Adeyemo WL, James O, Ogunlewe MO, Ladeinde AL, Taiwo OA, Olojede AL. Indications for extraction of third molars: a review of 1763 cases. Niiger Postgrad Med J. 2008;15(1):42-46.

15.Gbotolorun OM, Olojede AL, Arotiba GT, Ladeinde AL, Akinwande JA, Bamgboye BO. Impacted mandibular third molars: presentation and postoperative complications at the Lagos University Teaching Hospital. Nig Q J Hosp Med. 2007;17(1):26-29.

16. Bishara SE. Impacted maxillary canines: a review. Am J orthoddentofacialorthop.1992;101(2):159-171. doi:10.1016/08895406(92)70008-X

17. Wahid A, Milan FI, Bokhan SAH, Moazzam A, Kramat A, Khan F.
Prevalence of impacted mandibular and maxillary third molars: a radiographic study of patients reporting Madina teaching hospital, Faisalabad. JUMDC 2013;4(2):22-32.

18. Bamgbose BO, Akinwande JA, Adeyemo WL, Ladeinde AL, Arotiba GT, Ogunlewe MO. Effects of co-administered dexamethasone and diclofenac potassium on pain, swelling and trismus following third molar surgery. Head Face Med. 2005;1:11. doi: 10.1186/1746-160X$1-11$

19. Anjum R, Naseem N, Nagi AH. Age, genderand pattern distribution of impacted third molar among patients attending teaching hospital of Lahore. PJMHS.2014;8(3):562-565.

20. Alarcon JA, Bastir M, Rosas A. Variation of mandibular sexual dimorphism across human facial patterns. Homo J Comparative Human Biol. 2016;67:88-202. doi: 10.1016/j.jchb.2015.11.004

21.Odusanya SA, Abayomi IO. Third molar eruption among rural Nigerians. Oral Surg Oral Med Oral Pathol. 1991;71(2):151-154.

22. Breik 0 , Grubor D. The incidence of mandibular third molar impactions in different skeletal face types. Aust Dent J. 2008;53(4):320-324. doi: 10.1111/j.1834-7819.2008.00073.x

23. Abu Alhaija ESJ, albhairan HM, alkhateeb SN. Mandibular third molar space in different antero posterior skeletal patterns. Eur J Orthod. 2010;33(5):570-576. doi: 10.1093/ejo/cjq125

24. Toedtling V, Coulthard P, Thackray G. Distal caries of the second molar in the presence of a mandibular third molar-a prevention protocol. $\mathrm{Br}$ Dent J. 2016;221(6):297-302. doi: 10.1038/sj.bdj.2016.677

25. Oderinu OH, Adeyemo WL, Adeyemi MO, Nwathor O, Adeyemi MF. Distal cervical caries in second molars associated with impacted mandibular third molar: a case control study. Oral Surg Oral Med Oral Pathol Oral Radiol. 2012;4403(12):39-45. doi 10:1016/i.0000.2012.03.039

26. Wang D, He X, Wang Y, Li Z, Zhu Y, Sun C et al. External root resorption of the second molar associated with mesially and horizontally impacted mandibular third molar:evidence from cone beam computed tomography. Clin Oral Investig. 2016;10:1-8. doi 10.1007/500784016-1888-y 